九州大学学術情報リポジトリ

Kyushu University Institutional Repository

\title{
A NEW SPECIES OF ELASMIDAE FROM EAST AFRICA (Hymenoptera)
}

Yasumatsu, Keizo

https://doi.org/10.5109/2339

出版情報: ESAKIA. 1, pp.13-15，1960-01-20. Hikosan biological laboratory, Faculty of Agriculture, Kyushu University バージョン：

権利関係 : 


\section{A NEW SPECIES OF ELASMIDAE FROM EAST AFRICA* (Hymenoptera)}

\section{BY}

\section{Keizô Yasumatsu}

As a by-product of the culturing of many species of Embioptera, Dr. Edward S. Ross, of the California Academy of Sciences, has accumulated a very large collection of Sclerogibbidae and other insects associated with these little known orthopteroid hosts. Included in this material, which was recently sent to the author for study, are a number of wasps of other families which emerged from the cultures and thus may prove to be embiid parasites.

One of these represents a new species of elasmid from East Africa. If this wasp actually parasitized one of the embiids in the culture tube, this would constitute the first record of the family Elasmidae bred from the Embioptera. Because of the distinctive characters of the new species, the author unhesitatingly bases the new name on a single specimen, the holotype.

The author takes great pleasure in naming this species after Dr. Ross in recognition of his contributions to our knowledge of the Embioptera and their parasites and for his generosity in placing his material at the author's disposal.

\section{E lasmus rossi sp. nov.}

․ Black with metallic shine. Head, mesonotum and scutellum with dark greenish shine. Metanotum and propodeum with purplish shine. Antenna1 scape, pedicel and annellus pale brown, upper half of pedicel, funicle and club brownish. Legs brownish, fore coxae darker basally, mid- and hind coxae and femora brownish, apex of mid- and hind femora slightly paler. Abdomen with the lateral and ventral sides and the posterior margin of third to fifth tergites pale brownish, dorsum dark brownish, sixth and the following tergites almost entirely dark brownish.

* Contribution Ser. 2, No. 52, Entomological Laboratory, Kyushu University, Fukuoka.

Contribution Ser. 2, No. 4, Hikosan Biological Laboratory, Kyushu University, Hikosan. 
Head including eyes very slightly wider than thorax, strongly and comparatively sparsely punctate. Antennae: scape four times as long as wide at the middle, distinctly longer than pedicel; pedicel more than twice as long as wide at the apex, distinctly narrowed towards the base, narrower than scape; first segment of annellus very short and narrow, somewhat oblique, second segment of annellus. much longer and wider than the first, slightly narrower than the base of the first funicle segment; three funicle segments of equal length, each segment more than two and one-half times as long as wide, first and second of equal width, third very slightly wider than the second; club three segmented, distinctly shorter than the two funicle segments taken together, the first and second segment of equal width, the first distinctly longer than the second which is longer than the third, the first wider than the third funicle segment; upper portion of scape with denser semi-decumbent rigid hairs, the other segments with (pedicel with sparse) dense rigid semi-recumbent hairs. Ocelli arranged in an obtuse angled triangle ; lateral ocelli separated from the eye by a distance equal to their diameter and from the caudal margin of head by a distance equal to onethird their diameter.

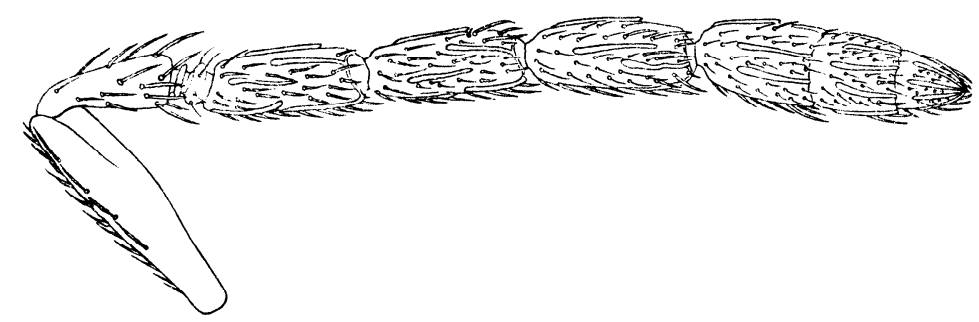

Fig. 1. Antenna of Elasmus rossi sp. nov., ?.

Mesonotum as wide as long. Scutellum about as wide as long. Postscutellum triangular, large, nearly one-third the length of scutellum, projecting over propodeum. Mesonotum shagreened, scutellum finely shagreened and almost smooth and shining. Propodeum smooth and shining. Legs with coxae broadened very much, femora less broadened, hind coxae with many striations, the ciliae in hind tibiae arranged in well defined lozenges. The measurements of the segments are as follows :

$\begin{array}{lcccc} & \text { Coxa } & \text { Femur } & \text { Tibia } & \text { Tarsus } \\ \text { Fore legs } & 7 & \mathbf{9} & 8 & 8 \\ \text { Mid-legs } & 8 & 10 & 13 & 18 \\ \text { Hind legs } & 10 & 11 & 14 & 20\end{array}$

(Comparative measurements :-Antenna (Except scape) 15, Fore wing 40, Hind wing 35, Maximum length of ey'e 7. 22 units $=1 \mathrm{~mm}$.)

Wings at rest reaching to the tip of abdomen, hyaline, ciliate to the base, with a regular row of ciliae near the hind margin and a hairless line along the 
hind margin.

Abdomen slightly longer than head and thorax taken together, about as wide as thorax, much pointed at apex, ovipositor slightly but distinctly projecting over end of abdomen.

Head and mesonotum covered with dense, short, brownish ciliae.

Length of body : ca. $2.5 \mathrm{~mm}$.

Holotype.-Female, deposited in the California Academy of Sciences (one antenna mounted on slide).

Type locality.-Kenya : 25 miles northwest of Nakuru (Mau Escarpment), altitude 2300 m., December 20, 1957 (E. S. Ross).

In Dr. Ferrière's key to Asiatic and African species of the genus Elasmus, the present species runs to Elasmus indicus Rohwer. Hut in indicus, each funicle segment is twice as long as wide, lateral ocelli are separated from the eye by a distance about twice as great as their diameter and from the caudal margin of the head by a distance equal to their diameter. This species is also allied to Elasmustolli Risbec of Africa, but the latter has the pedicel very slightly longer than wide and each funicle segment about as wide as long.

Remarks.---This wasp emerged from a culture of a small black species of the the family Teratembiidae (Embioptera) representing an undescribed genus and species. The actual emergence from an embiid host was not observed. Fragments of bark and other habitat material was present in the tube and this could have harbored the pupa of the wasp. The vegetation of the type locality is mountain forest mixed with bamboo. 